\title{
Differentiation of Tilletia Species by rep-PCR Genomic Fingerprinting
}

\author{
J. G. McDonald, E. Wong, and G. P. White, Centre for Plant Quarantine Pests, Canadian Food Inspection Agency, \\ 3851 Fallowfield Rd., Nepean, Ontario, K2H 8P9
}

\begin{abstract}
McDonald, J. G., Wong, E., and White, G. P. 2000. Differentiation of Tilletia species by repPCR genomic fingerprinting. Plant Dis. 84:1121-1125.

The potential of repetitive-sequence-based polymerase chain reaction (rep-PCR) fingerprinting of fungal genomic DNA as a rapid and simple alternative to random amplified polymorphic DNA (RAPD) analysis in the study of phylogenetic relationships, and also as a diagnostic method, was investigated with species of Tilletia. DNA primers (BOX, ERIC, and REP) corresponding to conserved repetitive element motifs, originally described in prokaryotes, were used to generate genomic fingerprints of $T$. indica, T. walkeri, T. controversa, T. laevis, T. tritici, $T$. goloskokovii, T. barclayana, and members of the T. fusca complex. Computer-assisted analysis of the database of combined fingerprints clearly distinguished each taxon and indicated phylogenetic relationships consistent with previously reported RAPD analyses. There were three main clusters with isolates showing 35 to $40 \%$ similarity. Group 1 included $T$. indica and $T$. walkeri; group 2 included members of the T. fusca complex, as well as T. controversa, T. laevis, T. tritici, and T. goloskokovii; and group 3 included only T. barclayana. If, as is likely, the conserved repetitive element motifs on which this technique is based are widespread or universal in fungal species, rep-PCR shows strong potential, not only as a simple generic taxonomic tool, but also as a diagnostic method.
\end{abstract}

There is increasing interest in the application of polymerase chain reaction (PCR) technology for the identification of plant pathogenic fungi. Such methods offer the advantage of reducing or eliminating the need for lengthy culturing and difficult morphological identification procedures $(11,27)$. The potential benefits of this technology have been especially recognized in the regulatory field, where timeliness and accuracy of identifications are crucial $(10,22)$.

An important area of application has been in tests to confirm the identity of teliospores of Tilletia spp. found in seed washes. With the discovery in 1996 of Tilletia indica in Arizona (26), there was a need to conduct national surveys of wheatproducing regions of the United States for Karnal bunt infection. In order to distinguish teliospores of $T$. indica from the morphologically similar $T$. barclayana, a PCR test was used that distinguished the two (22). This test used a single set of mitochondrial DNA primers that had also been validated against a number of other Tilletia spp. that were known to be common contaminants in grain shipments.

Corresponding author: J. G. McDonald

E-mail: mcdonalj@em.agr.ca

Accepted for publication 3 July 2000.

Publication no. D-2000-0808-01R

This article is in the public domain and not copyrightable. It may be freely reprinted with customary crediting of the source. The American Phytopathological Society, 2000.
However, soon after the survey was initiated, $T$. indica-like spores were unexpectedly found in seed lots of annual ryegrass (Lolium multiflorum), and they tested positive in the PCR confirmation test (16). After considerable further investigation, it was determined that the ryegrass smut was a distinct species, named $T$. walkeri $(4,5,18)$, and several new sets of mitochondrial DNA primers were developed that would make this distinction (8). This chronology was thus instructive on the risks associated with basing a PCR test on a single set of primers.

An alternative to identification using specifically targeted PCR primers is the use of PCR-based genomic fingerprinting. Whole genome techniques, such as random amplified polymorphic DNA (RAPD) analysis and amplified fragment length polymorphisms (AFLP), have been shown to be relatively robust and discriminatory (14). They are widely used in population and taxonomic studies but, due to their complexity, are not frequently used for identification. In taxonomic studies of Tilletia spp., including such species as $T$. indica, T. barclayana, T. walkeri, T. controversa, T. goloskokovii, T. laevis, T. tritici, and the T. fusca species complex, RAPD as well as the less sensitive PCRrestriction fragment length polymorphism (PCR-RFLP) analysis of the ITS region of rDNA have been used $(2,3,18,21)$. In general, these methods have identified groupings that were consistent with taxa that have been established principally on the basis of teliospore morphology, although they have also suggested significant divi- sions within those taxa based upon host specificity, indicating the need for further taxonomic refinements. One such division was in T. fusca var. fusca, where RAPD profiles of isolates on Vulpia octoflora shared only 20 to $35 \%$ similarity with isolates from Vulpia microstachys $(2,3)$.

Another genomic fingerprinting technique that is beginning to be used for identification, as well as taxonomic purposes, is repetitive-sequence-based polymerase chain reaction (rep-PCR) (24). The technique is based on PCR-mediated amplification of DNA sequences located between specific interspersed repeated sequences in prokaryotic genomes. These repeated elements are termed BOX, REP, and ERIC elements. Amplification of the DNA sequences between primers based on these repeated elements generates an array of different-sized DNA fragments from the genomes of individual strains. The separation of these fragments on agarose gels yields highly specific DNA fingerprints that can be either visually compared or subjected to computer assisted pattern analysis (19). Because of the simplicity of this approach, and also because rep-PCR can tolerate a wider range of DNA concentrations than RAPD analysis in generating reproducible results (14), it has proven useful not only in characterizing the variability within bacterial species but also in the identification of bacterial species, including plant pathogens (14).

Although rep-PCR primers were designed for repeated elements in prokaryotic genomes, BOX, ERIC, and REP primers have been shown to also amplify interrepeat sequences of some fungal genomes and have been used to characterize variability at inter- and/or intra-specific levels of several fungal genera, including Verticillium (1), Fusarium (7), Stagonospora (6), Septoria (6), and Leptosphaeria (13). Additional endogenous repetitive DNA elements have also been identified in fungi and used to generate genomic fingerprints $(9,13)$. However, there have been no studies to determine the applicability of repPCR genomic fingerprinting for the identification of fungal species, whether for taxonomic or other purposes. Therefore, the current study was initiated to examine this potential with respect to species of Tilletia.

\section{MATERIALS AND METHODS}

Fungal isolates and DNA extraction. Sixty-seven isolates representing $11 \mathrm{Til}$ letia taxa were used (Table 1). Teliospores 
of $T$. indica and T. barclayana were surface-sterilized with a $10 \%$ commercial bleach (sodium hypochlorite) solution, while the remainder were treated with a $5 \%$ solution. They were then streaked on $2 \%$ water agar to germinate. Incubation temperatures were: room temperature for T. indica, T. walkeri, and T. barclayana; $16^{\circ} \mathrm{C}$ for T. tritici, T. laevis, T. goloskokovii, and T. fusca; and $5^{\circ} \mathrm{C}$ for T. controversa. After germination, the procedures of Smith et al. (22) were used to obtain a mycelial mat. DNA was then extracted from the mycelial mat using the procedure of Möller et al. (15).

Rep-PCR amplification and analysis. DNA from the fungal isolates listed in Table 1 was subjected to rep-PCR genomic fingerprinting using primer sets corresponding to the BOX, ERIC, and REP elements (24). The primer sets included BOX element $1 \mathrm{~A}$ primer $1 \mathrm{R} \quad\left(5^{\prime}-\right.$ CTACGGCAAGGCGACGCTGACG-3'); ERIC primers 1R (5'-ATGTAAGCTCCT GGGGATTCAC-3') and 2I (5'-AAGTAA GTGACTGGGGTGAGCG-3'); and REP primers 1R (5'-IIIICGICGICATCIGGC-3') and 2I (5'-ICGICTTATCIGGCCTAC-3'). The rep-PCR protocols were carried out as described by Rademaker et al. (20). Briefly, 50 ng of purified DNA was used as template in a 25 - $\mu$ l reaction mixture containing $50 \mu \mathrm{M}$ of each primer, $900 \mu \mathrm{M}$ deoxynucleotide triphosphates, and 2 units of Taq DNA polymerase (Gibco BRL, Burlington, $\mathrm{ON}$ ) in a reaction buffer containing $67 \mathrm{mM}$ Tris- $\mathrm{HCl}(\mathrm{pH} 8.8), 16.6$ $\mathrm{mM}\left(\mathrm{NH}_{4}\right)_{2} \mathrm{SO}_{4}, 6.7 \mathrm{mM} \mathrm{MgCl} 2,6.7 \mathrm{mM}$ EDTA, $30 \mathrm{mM}$ 2-mercaptoethanol, $4 \mu \mathrm{g}$ of bovine serum albumin, and $10 \%$ dimethylsulfoxide (vol/vol). PCR amplifications were performed in a model PE 9700 Perkin-Elmer thermocycler (Perkin-Elmer, Norwalk, CT) using the following conditions: an initial denaturation at $95^{\circ} \mathrm{C}$ for 7 min: 35 cycles consisting of $94^{\circ} \mathrm{C}$ for $3 \mathrm{~s}$, $92^{\circ} \mathrm{C}$ for $30 \mathrm{~s}$, then either $40^{\circ} \mathrm{C}$ (REP primers) or $50^{\circ} \mathrm{C}$ (ERIC/BOX primers) for $1 \mathrm{~min}$; extension at $65^{\circ} \mathrm{C}$ for $8 \mathrm{~min}$; and a single final extension at $65^{\circ} \mathrm{C}$ for $8 \mathrm{~min}$, followed by cooling at $4^{\circ} \mathrm{C}$. To determine reproducibility, all samples were subjected at least twice to independent PCR and electrophoresis, and reaction products were duplicated on the same gel.

BOX, ERIC, and REP primers were synthesized by Gibco BRL. DNA fragments in $8 \mu \mathrm{l}$ of the amplified PCR product were separated by gel electrophoresis at $4^{\circ} \mathrm{C}$ on $1.5 \%$ agarose (Seakem LE, FMC BioProducts, Rockland, ME) gels in Trisacetate-EDTA (TAE; $0.4 \mathrm{M}$ Tris-acetate and $1 \mathrm{mM}$ EDTA, $\mathrm{pH}$ 8.0) buffer for 18 to $19 \mathrm{~h}$ at $2 \mathrm{~V} / \mathrm{cm}$, stained with ethidium bromide, and photographed on a UV transilluminator using a Speedlight Platinum Jr. digital image capture gel documentation system (Lightools Research, Encinitas, CA). Digital images of the gels were subjected to analysis using the commercially available GelCompar software (version 4.0; Applied Maths, Kortrijk, Belgium). Gels were normalized using the same standards (1-kb DNA ladder; Gibco BRL), loaded on both sides and in the center of 20-lane gels. The "rolling disk" background subtraction option was applied. The BOX-, ERIC-, and REP-PCR genomic fingerprints were linearly combined using the "combined gel" option of GelCompar. The similarity between pairs of linearly combined fingerprints was calculated using the product-moment correlation coefficient ( $r$ value) (17) and applied to the whole densitometric curves of the gel tracks (12). Cluster analysis of the pairwise similarly values was performed using the unweighted pair group method using arithmetic averages (23) clustering technique. Fingerprint patterns were reconstructed as described (19).

\section{RESULTS AND DISCUSSION}

Amplification of total DNA from the different isolates of Tilletia with the ERIC-, BOX-, and REP-primers followed by agarose gel electrophoresis of the PCR prod- ucts resulted in complex fingerprint patterns (Fig. 1). Rep-PCR fingerprint patterns for an isolate of each Tilletia species were examined. The size of the amplification products ranged from approximately $100 \mathrm{bp}$ up to $4,000 \mathrm{bp}$. Each primer set generated $\sim 25$ to 30 bands visible on the densitometric curves of the gel tracks.

In analyzing the reproducibility of the rep-PCR, comparison of the resulting fingerprint patterns yielded a similarity of $\sim 90$ to $95 \%$ when the patterns were generated in the same PCR experiment and resolved on the same gel, while independent PCR and electrophoresis of repeated samples resulted in similarities of $\sim 85$ to $90 \%$ (data not shown). These values are consistent with those from rep-PCR studies on prokaryotes (25).

Analysis of the combined BOX-, ERIC-, and REP-PCR patterns revealed that the isolates clustered together into three major groups designated 1 to 3 (Fig. 2). Group 1 contained two separate clusters of $T$. indica and T. walkeri isolates that shared a similarity of $\sim 30 \%$. The isolates of T. indica and T. walkeri shared $\sim 40 \%$ and $\sim 75 \%$

Table 1. Collections of Tilletia species isolates used in study designated by isolate number, origin, date collected, host and supplier

\begin{tabular}{|c|c|c|c|c|}
\hline Isolate $^{a}$ & Collection ID & Origin/year & Host & Supplier ${ }^{b}$ \\
\hline \multicolumn{5}{|c|}{ Tilletia indica } \\
\hline 10 & 960507 & Mexico, 1996 & Triticum sp. & GPW \\
\hline 11 & 970402 & India, 1997 & Triticum sp. & $\mathrm{SSC}$ \\
\hline 32 & P91 & India, 1991 & Triticum sp. & MRB \\
\hline 34 & D97 & India, 1997 & Triticum sp. & MRB \\
\hline 35 & G97 & India, 1997 & Triticum sp. & MRB \\
\hline 36 & H97 & India, 1997 & Triticum sp. & MRB \\
\hline 37 & $\mathrm{~J} 97$ & India, 1997 & Triticum sp. & MRB \\
\hline 38 & $\mathrm{CO} 81$ & Mexico, 1981 & Triticum sp. & MRB \\
\hline 39 & S85 & Mexico, 1985 & Triticum sp. & MRB \\
\hline 42 & $\mathrm{CO} 96$ & Mexico, 1996 & Triticum sp. & MRB \\
\hline 44 & P85 & Pakistan, 1985 & Triticum sp. & MRB \\
\hline 45 & P86 & Pakistan, 1986 & Triticum sp. & MRB \\
\hline 84 & 17377 & Pakistan, 1997 & Triticum sp. & GPW \\
\hline 85 & 17202 & Pakistan, 1997 & Triticum sp. & GPW \\
\hline 90 & 17375 & Pakistan, 1997 & Triticum sp. & GPW \\
\hline 97 & 15993 & Pakistan, 1997 & Triticum sp. & GPW \\
\hline 98 & 16005 & Pakistan, 1997 & Triticum sp. & GPW \\
\hline 101 & 16014 & Pakistan, 1997 & Triticum sp. & GPW \\
\hline 112 & 15514 & Pakistan, 1997 & Triticum sp. & GPW \\
\hline 115 & 15044 & Pakistan, 1997 & Triticum sp. & GPW \\
\hline \multicolumn{5}{|c|}{ T. walkeri } \\
\hline 1 & M96447 & Oregon, USA, 1996 & Lolium multiflorum & GPW \\
\hline 2 & M96504 & Oregon, USA, 1996 & L. multiflorum & GPW \\
\hline 3 & P195GR3 & Oregon, USA, 1996 & L. multiflorum & GMI \\
\hline 4 & LA146AT5 & Oregon, USA, 1996 & L. multiflorum & GMI \\
\hline 23 & 770 & Oregon, USA, 1997 & L. multiflorum & BJG \\
\hline 71 & P195GR3 & Oregon, USA, 1998 & L. multiflorum & GMI \\
\hline $147^{c}$ & 196 & Oregon, USA, 1996 & L. multiflorum & LMC \\
\hline $148^{\mathrm{c}}$ & 770 & Tennessee, USA, 1997 & L. multiflorum & LMC \\
\hline $149^{c}$ & TR1T11 & Tennessee, USA, 1996 & L. multiflorum & LMC \\
\hline 171 & M96424 & Oregon, USA, 1996 & L. multiflorum & GPW \\
\hline 173 & M964596 & Oregon, USA, 1996 & L. multiflorum & GPW \\
\hline
\end{tabular}

(continued on next page)

${ }^{a}$ From single teliospores, except where indicated.

${ }^{\mathrm{b}}$ GPW = G. P. White, CFIA, Nepean, ON, Canada; SSC = S. S. Chahal, Department of Plant Pathology, PAW, Ludhiama, India; MRB = M. R. Bonde, USDA-ARS, Frederick, MD; GMI = G. M. Milbrath, Plant Division, Oregon Department of Agriculture, Salem, OR; BJG = B. J. Goates, USDA, Aberdeen, ID; LMC = L. M. Carris, Department of Plant Pathology, Washington State University, Pullman; GMU = G. M. Murray, NSW Agriculture, Wagga Wagga, New South Wales, Australia.

${ }^{\mathrm{c}}$ Provided as a single sporangial culture. 
similarity, respectively. Group 2 contained separate clusters of $T$. fusca var. fusca on $V$. microstachys, T. goloskokovii, T. fusca var. fusca, on V. octoflora, T. fusca var. bromitectorum, T. fusca var. guyotiana, T. controversa, T. tritici, and T. laevis isolates that shared a similarity of $\sim 40 \%$. Within the group, isolates of the two T. fusca var. fusca taxa and T. goloskokovii each clustered separately and showed only $\sim 45 \%$ similarity to each other. The remaining taxa formed a cluster with $\sim 55 \%$ similarity, and T. fusca var. bromi-tectorum and T. fusca var. guyotiana formed one subcluster with $\sim 60 \%$ similarity, while $T$. controversa, T. laevis, and T. tritici formed another subcluster with $\sim 70 \%$ similarity. Group 3 included just $T$. barclayana isolates, and these shared a similarity of $\sim 30 \%$.

Previous genomic fingerprinting studies of Tilletia species, using RAPD analysis, have used various random primers to analyze different subsets of taxa $(2,3,18,21)$. Consequently, a combined analysis of all these taxa, with a common set of PCR primers, has not previously been at- tempted. However, the relationships revealed in this study are generally consistent with the RAPD analyses that have been made $(2,3,18,21)$. It should be noted, however, that the present study differs from previous analyses by principally using polysporidial rather than monosporidial lines.

In a study of $T$. indica, $T$. walkeri, and $T$. barclayana isolates, Pimentel et al. (18) also found that separate clusters of $T$. indica and $T$. walkeri formed a group that shared a similarity of $\sim 25 \%$. Also consistent with the present study was the fact that, within the clusters of $T$. indica and $T$. walkeri, isolates had similarities of 50 and $78 \%$, respectively. Among the T. barclayana isolates, which are considered to be a species complex (18), they observed $<10 \%$ similarity.

Isolates of T. controversa, T. fusca var. bromi-tectorum, T. fusca var. guyotiana, and T. fusca var. fusca on V. microstachys as well as $V$. octoflora, have been compared in two studies $(2,3)$, with $T$. goloskokovii being included in one of the studies

Table 1. (continued)

\begin{tabular}{|c|c|c|c|c|}
\hline Isolate $^{\mathbf{a}}$ & Collection ID & Origin/year & Host & Supplierb \\
\hline \multicolumn{5}{|c|}{ T. controversa } \\
\hline 19 & 756 & Idaho, USA, 1997 & Triticum sp. & BJG \\
\hline 20 & 638 & Idaho, USA, 1997 & Triticum sp. & BJG \\
\hline 54 & M973111 & Ontario, Canada, 1997 & Triticum sp. & GPW \\
\hline 56 & M973133 & Ontario, Canada, 1997 & Triticum sp. & GPW \\
\hline 57 & M973144 & Ontario, Canada, 1997 & Triticum sp. & GPW \\
\hline 59 & M973166 & Ontario, Canada, 1997 & Triticum sp. & GPW \\
\hline 60 & M973177 & Ontario, Canada, 1997 & Triticum sp. & GPW \\
\hline 61 & M973188 & Ontario, Canada, 1997 & Triticum sp. & GPW \\
\hline 62 & M973199 & Ontario, Canada, 1997 & Triticum sp. & GPW \\
\hline 128 & M98073 & Ontario, Canada, 1997 & Triticum sp. & GPW \\
\hline 151 & 177 & Utah, USA, 1985 & Triticum sp. & LMC \\
\hline \multicolumn{5}{|c|}{ T. barclayana } \\
\hline 25 & ST96 & Arkansas, 1996 & Oryza sativa & BJG \\
\hline 51 & M97228 & California, USA, 1997 & O. sativa & GPW \\
\hline 67 & M97016 & China, 1997 & O. sativa & GPW \\
\hline 69 & M97619 & Philippines, 1997 & O. sativa & GPW \\
\hline 162 & RDC9T5 & Arkansas, 1992 & O. sativa & LMC \\
\hline 163 & FNL1 & Arkansas, 1996 & O. sativa & LMC \\
\hline 177 & M98377 & Arizona, 1998 & O. sativa & GPW \\
\hline \multicolumn{5}{|l|}{ T. laevis } \\
\hline 74 & 17399 & Pakistan, 1997 & Triticum sp. & GPW \\
\hline 124 & 72299 & Australia, 1997 & Triticum sp. & GMU \\
\hline 125 & 73300 & Australia, 1997 & Triticum sp. & GMU \\
\hline 127 & 73302 & Australia, 1997 & Triticum sp. & GMU \\
\hline 166 & V-766 & Iran, 1992 & Triticum sp. & LMC \\
\hline \multicolumn{5}{|l|}{ T. tritici } \\
\hline 21 & $\mathrm{~T} 2$ & Idaho, USA, 1996 & Triticum sp. & BJG \\
\hline 22 & $\mathrm{~T} 16$ & Idaho, USA, 1996 & Triticum sp. & BJG \\
\hline 63 & M9732010 & Ontario, Canada, 1997 & Triticum sp. & GPW \\
\hline \multicolumn{5}{|c|}{ T. fusca var. bromi-tectorum } \\
\hline 152 & 2 & Washington, USA, 1991 & Bromus tectorum & LMC \\
\hline 153 & 316 & Washington, USA, 1995 & B. tectorum & LMC \\
\hline \multicolumn{5}{|c|}{ T. fusca var. fusca } \\
\hline 154 & $314 \mathrm{~A}$ & Washington, USA, 1995 & Vulpia microstachys & LMC \\
\hline 155 & 344 & Washington, USA, 1996 & $V$. microstachys & LMC \\
\hline 156 & $314 \mathrm{~A}$ & Washington, USA, 1995 & V. octoflora & LMC \\
\hline 157 & $318 \mathrm{~B}$ & Washington, USA, 1995 & V. octoflora & LMC \\
\hline \multicolumn{5}{|c|}{ T. fusca var. guyotiana } \\
\hline 158 & 64 & Idaho, USA, 1991 & B. japonicus & LMC \\
\hline 159 & 74 & Oregon, USA, 1991 & B. japonicus & LMC \\
\hline \multicolumn{5}{|c|}{ T. goloskokovii } \\
\hline 160 & 321 & Washington, USA, 1995 & Aptera interrupta & LMC \\
\hline 161 & 359 & Washington, USA, 1998 & A. interrupta & LMC \\
\hline
\end{tabular}

A

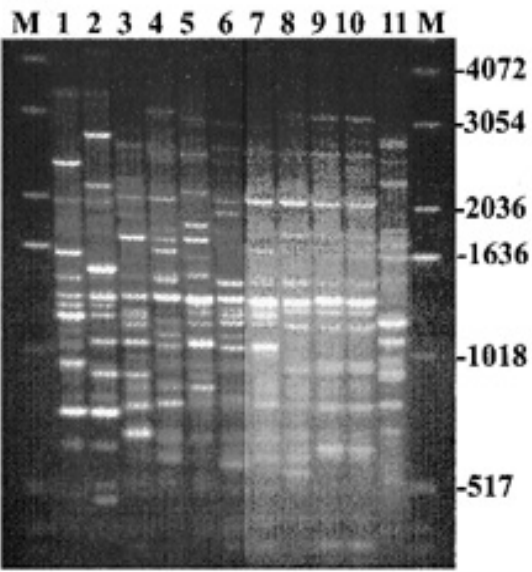

B

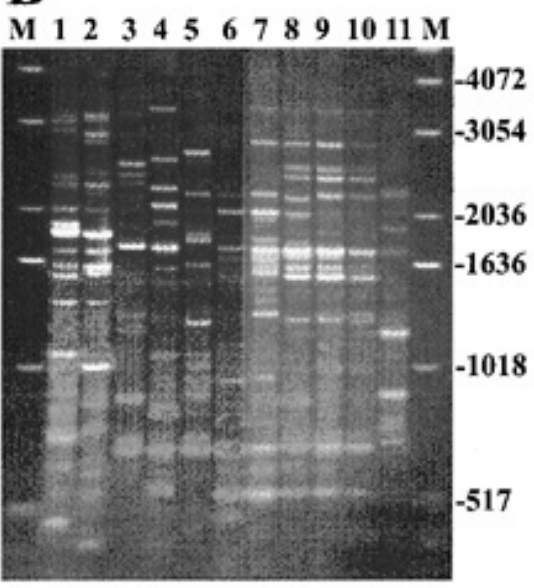

C

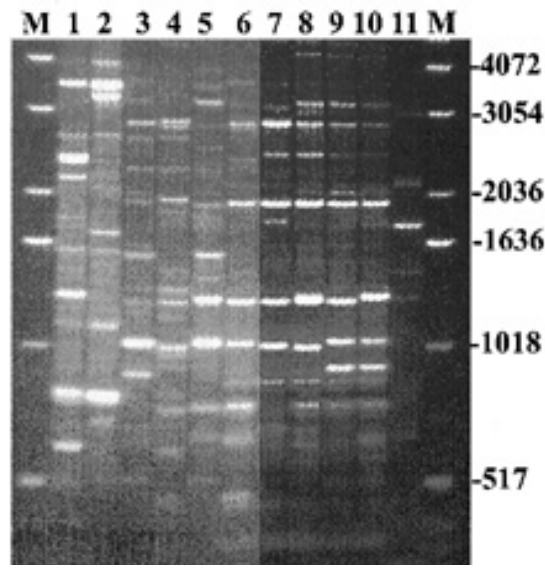

Fig. 1. Agarose gel electrophoresis of polymerase chain reaction (PCR) fingerprint patterns obtained from isolates representing 11 taxa of Tilletia using primers corresponding to repetitive extrapalindromic sequences (rep-PCR). (A) BOX-PCR, (B) ERIC-PCR, and (C) REP-PCR. A 6- $\mu$ l portion of each rep-PCR mixture was loaded onto a $1.5 \%$ agarose gel. Lane $1=T$. indica isolate 90; lane $2=$ T. walkeri isolate 173; lane $3=T$. fusca var. fusca on Vulpia microstachys isolate 154; lane $4=T$. goloskokovii isolate 160 ; lane $5=T$. fusca var. fusca on V. octoflora isolate 157; lane $6=T$. fusca var. bromi-tectorum isolate 152 ; lane $7=T$. fusca var. guyotiana isolate 158 ; lane $8=T$. controvers isolate 19 ; lane $9=T$. tritici isolate 22 ; lane $10=T$. laevis isolate 74; lane $11=T$. barclayana isolate 47. Lane $\mathrm{M}=\mathrm{DNA}$ molecular size markers (1 kbp ladder); sizes in base pairs. 
(3). T. fusca var. fusca isolates on V. microstachys and $V$. octoflora showed the greatest differences from the other species, but these two taxa showed only 20 to $35 \%$ similarity with each other, which is con- sistent with our results. Analyses of $T$. controversa, $T$. fusca var. guyotina, T. fusca var. bromi-tectorum, and T. goloskokovii isolates revealed somewhat greater differences among these taxa than found here, in that they were found to share only $\sim 25 \%$ similarity $(2,3)$. These latter two species were more similar to each other than they were to the others (3), which is also what our data show.

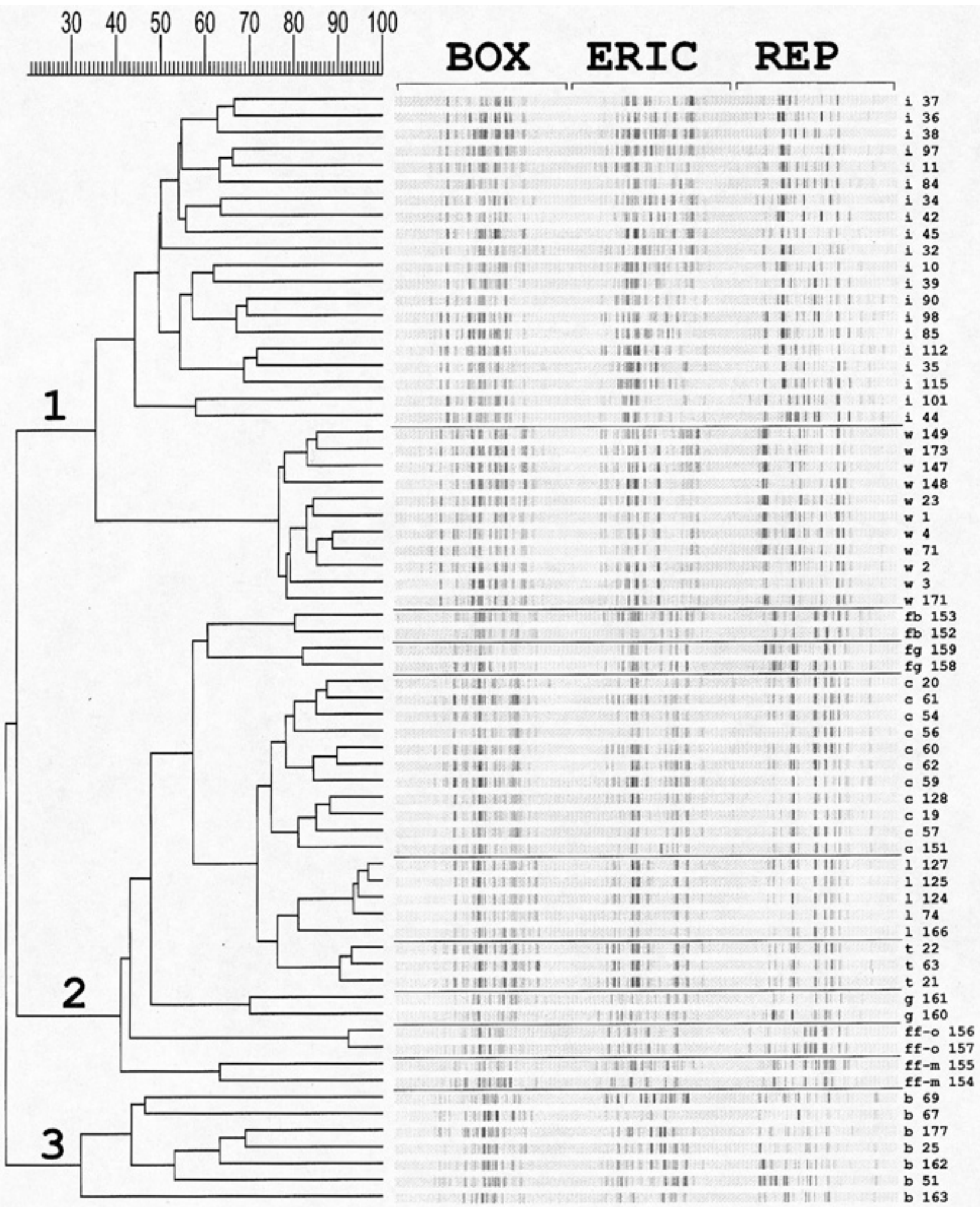

Fig. 2. Similarity of isolates of Tilletia spp. based on the presence and absence of bands generated using primers corresponding to repetitive extragenic palindromic sequences (REP), BOX1A sequences (BOX), enterobacterial repetitive intergenic consensus sequences (ERIC), and analyzed using the product-moment correlation coefficient $(r) ; \mathrm{i}=$ T. indica isolates, $\mathrm{w}=T$. walkeri, $\mathrm{ff}-\mathrm{m}=T$. fusca var. fusca on Vulpia microstachys, $\mathrm{g}=T$. goloskokovii, $\mathrm{ff}-\mathrm{o}=$ T. fusca var. fusca on V. octoflora, $\mathrm{fb}=T$. fusca var. bromi-tectorum, $\mathrm{fg}=T$. fusca var. guyotiana, $\mathrm{c}=T$. controversa, $\mathrm{t}=T$. tritici, $1=T$. laevis, $\mathrm{b}=T$. barclayana. Three major groupings are designated 1 to 3. 
In a study of a large number of isolates of wheat bunt fungi (21), RAPD analysis identified considerable diversity among $T$. controversa isolates, with some isolates clustering together and others clustering with isolates of $T$. laevis and/or T. tritici. Rep-PCR analysis also identified considerable diversity among the $T$. controversa isolates and close similarity to isolates of T. laevis and T. tritici; however, each species clustered separately.

The results of this study demonstrate the usefulness of rep-PCR genomic fingerpinting as a complementary or alternate strategy to RAPD analysis for studying phylogenetic relationships of fungi. The major advantages of this approach are its simplicity, the universality of PCR primers, tolerance of a wider range of DNA concentrations in generating reproducible results, and amenability to computer database analysis. In addition, it has potential as a diagnostic method (14) and would be particularly applicable in situations where isolation and culture are a normal requirement and speed and accuracy are at a premium. For example, application of repPCR in support of the $T$. indica testing program would have readily determined the distinct identity of $T$. indica-like spores found in seed lots of annual ryegrass $(4,16,18)$ and would have avoided the needless confusion and delay that resulted from this quarantine testing problem.

\section{ACKNOWLEDGMENTS}

We thank Dawn Martin for excellent technical assistance in culturing the Tilletia spp. teliospores and purifying the DNA, and Gary Kristjansson for valuable assistance during the early phases of the investigation. We also thank the suppliers, listed in Table 1, for the Tilletia isolates.

\section{LITERATURE CITED}

1. Arora, D. K., Hirsch, P. R., and Kerry, B. R. 1996. PCR-based molecular discrimination of Verticillium chlamydosporum isolates. Mycol. Res. 100:801-809.

2. Boyd, M. L., and Carris, L. M. 1997. Molecular relationships among varieties of the Tilletia fusca (T. bromi) complex and related species. Mycol. Res. 101:269-277.

3. Boyd, M. L., Carris, L. M., and Gray, P. M. 1998. Characterization of Tilletia goloskokovii and allied species. Mycologia 90:310-322.

4. Castlebury, L. A., and Carris, L. M. 1999.
Tilletia walkeri, a new species on Lolium multiflorum and L. perenne. Mycologia 91:121-131.

5. Cunfer, B. M., and Castlebury, L. A. 1999. Tilletia walkeri on annual ryegrass in wheat fields in the southeastern United States. Plant Dis. 83:685-689.

6. Czembor, P. C., and Arseniuk, E. 1999. Study of genetic variability among monopycnidial and monopycnidiospore isolates derived from single pycnidia of Stagonospora spp. and Septoria tritici with the use of RAPD-PCR, MP-PCR and rep-PCR techniques. J. Phytopathol. 147:539-546.

7. Edel, V., Steinberg, C., Avelange, I., Laguerre, G., and Alabouvette, C. 1995. Comparison of three molecular methods for the characterization of Fusarium oxysporum strains. Phytopathology 85:579-585.

8. Frederick, R. D., Snyder, K. E., Tooley, P. W., Berthier-Schaad, Y., Peterson, G. L., Bonde, M. R., Schaad, N. W., and Knorr, D. A. 1998. An improved PCR method utilizing TaqMan for the detection and differentiation of Tilletia indica, the causal organism of Karnal bunt of wheat, and a related ryegrass smut. Phytopathology 88:S29.

9. George, M. L. C., Nelson, R. J., Zeigler, R. S., and Leung, H. 1998. Rapid population analysis of Magnaporthe grisea by using rep-PCR and endogenous repetitive DNA sequences. Phytopathology 88:223-229.

10. Goodwin, P. H., and Annis, S. L. 1991. Rapid identification of genetic variation and pathotype of Leptosphaeria maculans by random amplified polymorphic DNA assay. Appl. Environ. Microbiol. 57:2482-2486.

11. Hamelin, R., Ouellette, G. B., and Bernier, L. 1993. Identification of Gremmeniela abietina races with random amplified polymorphic DNA markers. Appl. Environ. Microbiol. 59:1752-1755.

12. Häne, B. G., Jäger, K., and Drexler, H. 1993. The Pearson product-moment correlation coefficient is better suited for identification of DNA fingerprint profiles than band matching algorithms. Electrophoresis 14:967-972.

13. Jedryczka, M., Rouxel, T., and Balesdent, M.H. 1999. Rep-PCR based genomic fingerprinting of isolates of Leptosphaeria maculans from Poland. Eur. J. Plant Pathol. 105:813-823.

14. Louws, F. J., Rademaker, J. L. W., and de Bruijn, F. J. 1999. The three Ds of PCR-based genomic analysis of phytobacteria: Diversity, detection and disease diagnosis. Annu. Rev. Phytopathol. 37:81-125.

15. Möller, E. M., Bahnweg, G., Sandermann, H., and Geiger, H. H. 1992. A simple and efficient protocol for the isolation of high molecular weight DNA from filamentous fungi, fruit bodies, and infected plant tissues. Nucleic Acids Res. 20:6115-6116.
16. Palm, M. E. 1999. Mycology and world trade A view from the front line. Mycologia 91:112.

17. Pearson, K. 1926. On the coefficient of racial likeness. Biometrika 8:105-117.

18. Pimentel, G., Carris, L. M., Levy, L., and Meyer, R. J. 1998. Genetic variability among isolates of Tilletia barclayana, T. indica and allied species. Mycologia 90:1017-1027.

19. Rademaker, J. L. W., and de Bruijn, F. J. 1997. Characterization and classification of microbes by rep-PCR geno mic fingerprinting and computer-assisted pattern analysis. Pages 151-171 in: DNA Markers: Protocols, Applications and Overviews. G. Caetano-Anollés and P. M. Gresshoff, eds. John Wiley \& Sons, New York.

20. Rademaker, J. L. W., Louws, F. J., and de Bruijn, F. J. 1997. Characterization of the diversity of ecologically important microbes by rep-PCR genomic fingerprinting. Pages 1-26 in: Molecular Microbial Ecology Manual. A. D. L. Akkermans, J. D. van Elsas, and F. J. de Bruijn, eds. Kluwer Academic Publishers, Dordrecht, Netherlands.

21. Shi, Y. L., Loomis, P., Christian, D., Carris, L. M., and Leung, H. 1996. Analysis of the genetic relationships among the wheat bun fungi using RAPD and ribosomal DNA markers. Phytopathology 86:311-318.

22. Smith, O. P., Peterson, G. L., Beck, R. J., Schaad, N. W., and Bonde, M. R. 1996. Development of a PCR-based method for identification of Tilletia indica, causal agent of Karnal bunt of wheat. Phytopathology 86:115-122.

23. Sneath, P. H. A., and Sokal, R. R. 1973. Numerical Taxonomy. Freeman, San Francisco.

24. Versalovic, J., Koeuth, T., and Lupski, J. R. 1991. Distribution of repetitive DNA sequences in eubacteria and application to fingerprinting of bacterial genomes. Nucleic Acids Res. 19:6823-6831.

25. Vinuesa, P., Rademaker, J. L. W., de Bruijn, F. J., and Werner, D. 1998. Genotypic characterization of Bradyrhizobium strains nodulating endemic woody legumes of the Canary Islands by PCR-restriction fragment length polymorphism analysis of genes encoding $16 \mathrm{~S}$ rRNA (16SDNA) and 16S-23S rDNA intergenic spacers, repetitive extragenic palindromic PCR genomic fingerprinting, and partial 16S rDNA sequencing. Appl. Environ. Microbiol. 64:2096-2104.

26. Ykema, R. E., Floyd, J. P., Palm, M. E., and Peterson, G. L. 1996. First report of Karnal bunt of wheat in the United States. Plant Dis. 80:1207.

27. Zhang, A. W., Hartman, G. L., Curio-Penny, B., Pedersen, W. L., and Becker, K. B. 1999 Molecular detection of Diaporthe phaseolorum and Phomopsis longicolla from soybean seeds. Phytopathology 89:796-804. 